Selcuk Journal of Agriculture and Food Sciences

http://sjafs.selcuk.edu.tr/sjafs/index

Research Article
SJAFS

(2019) 33 (3), 248-251

e-ISSN: $2458-8377$

DOI:10.15316/SJAFS.2019.184

\title{
The Effects of Addition to Different Levels of Mealworm (Tenebrio molitor) to Quail Diets on Performance and Carcass Traits
}

\author{
Hilal SABIRLI ${ }^{1}$, Yusuf CUFADAR ${ }^{1 *}$ \\ ${ }^{1}$ Selcuk University, Faculty of Agriculture, Department of Animal Science, Konya, Turkey
}

\begin{tabular}{l}
\hline ARTICLE INFO \\
\hline Article history: \\
Received date: 23.08 .2019 \\
Accepted date: 03.10 .2019 \\
\hline Edited by: \\
İbrahim AYTEKİN; Selçuk University, \\
Turkey \\
Reviewed by: \\
Erinç GÜMÜŞ; Aksaray University, \\
Turkey \\
Gürkan KELEŞ; Adnan Menderes \\
University, Turkey \\
\hline Keywords: \\
Carcass traits \\
Mealworm \\
Performance \\
Quail
\end{tabular}

\section{Introduction}

There is a need for diets that require higher amounts of protein to meet the amino acid requirements in order to increase the growth rate and egg production of poultry (Hossain and Blair, 2007). However, the amino acid composition of plant-based proteins for poultry is lower than that of animal-based proteins, particularly in terms of the content of substantially sulphur-containing amino acids such as methionine. Soybean meal is the most widely used source of vegetable protein in dietary formulations for poultry due to its high quality and quantity of protein and sufficient amino acid profile (Veldkamp et al., 2012). In order to solve this problem and make poultry production sustainable in the future, quality alternative protein sources are needed. Recently, high demand for fish meal has led to an increase in its price. In addition, increasing production pressure on aquaculture has led to an increase in the research for insect proteins for aquaculture and livestock production (FAO, 2013). Researching alternative and sustainable animal protein sources is an important issue that requires viable solutions in the short term and makes insects increasingly

\footnotetext{
*Corresponding author email: yusufcufadar@gmail.com
}

attractive. In recent years, the potential for the use of insect-derived protein sources in poultry diets has attracted much attention. Some insect species have been proposed as an alternative feed additive due to their high protein $(30-70 \% \mathrm{KM})$ and fat content $(30-40 \%$ $\mathrm{KM}$ ). The yellow mealworm (Tenebrio molitor) is native to Europe and is a recognized pest of grain and cereal products (Ramos-Elorduy et al. 2002). The mealworm contains high amounts of crude protein (47$60 \%$ ) and fat (31-43\%). Fresh larvae of mealworm have a dry matter of $40 \%$ and a crude ash content of 1$4.5 \%$.

Some authors suggest that insects may be important as an alternative source of protein for poultry nutrition (Ramos-Elorduy et al. 2002; Veldkamp et al. 2012; Makkar et al. 2014; Sánchez-muros et al. 2014; van Huis 2015). The effects of mealworm supplementation to the poultry diets on growth performance (Bovera et al., 2015; Bovera et al., 2016; Biasato et al., 2016) and carcass characteristics (Ballitoc and Sun, 2013; Bovera et al., 2016; Biasato et al., 2016) have been recently investigated. Biasato et al. (2016) confirmed that the inclusion of the yellow meal worm did not affect the performance of free-range chickens, so that mealworm could be used safely in poultry diets. In another study, these researchers (Biasato et al., 2018) suggested that increasing levels of dietary mealworm meal inclusion 
in broiler diets may improve body weight and feed intake. In addition, due to its high nutrient digestibility, mealworms were reported to be an alternative protein source for soybean meal and fish meal (Bovera et al. 2015).

The study aimed to evaluate growth performance and carcass traits of quail chicks fed diets including mealworm meal in order to determine optimum level.

\section{Materials and Methods}

A total of 200 mixed sex one-day-old quail chicks were randomly allotted to 4 dietary treatments, each consisting of 5 pens as replicates with 10 chicks per pen. During the first 3 weeks, the animals were heated by halogen lamps to maintain the suitable temperature according to standard breeding practices. Lighting schedule was $23 \mathrm{~h}$ light: $1 \mathrm{~h}$ darkness during the experiment. The yellow mealworm larvae (Tenebrio molitor) was obtained from the company in commercial production (Mira Ltd. Şti., Aksu-Antalya). The larvae were submerged in a boiling water bath for $3 \mathrm{~min}$, dried in an oven at $80^{\circ} \mathrm{C}$ temperature, then milled.

A diet based on corn and soybean meal was formulated and served as control, while 2, 4, and $6 \%$ mealworm larvae meal inclusion as a partial replacement of

Table 1

Composition of experimental diets (as fed)

\begin{tabular}{lcccc}
\hline \multirow{2}{*}{ Ingredients (\%) } & \multicolumn{3}{c}{ Dietary Mealworm Levels (\%) } \\
\cline { 2 - 4 } & 0 & 2 & 4 & 6 \\
\hline Corn & 50.1 & 50.0 & 50.0 & 52.0 \\
Soybean Meal (44 \% CP) ${ }^{1}$ & 42.5 & 40.3 & 38.2 & 35.8 \\
Mealworm Meal (51 \% CP) ${ }^{1}$ & --- & 2.0 & 4.0 & 6.0 \\
Sand & --- & 1.1 & 2.0 & 1.8 \\
Vegetable oil & 3.4 & 2.9 & 2.4 & 2.5 \\
Limestone & 1.1 & 1.6 & 2.2 & 1.8 \\
Dicalcium phosphate & 2.2 & 1.4 & 0.5 & --- \\
Salt & 0.3 & 0.3 & 0.3 & 0.3 \\
Vitamin-Mineral Premix ${ }^{2}$ & 0.25 & 0.25 & 0.25 & 0.25 \\
L-Lysine & 0.15 & 0.15 & 0.15 & 100 \\
TOTAL & 100 & 100 & 100 & 24.14 \\
\hline Calculated Nutrients & & & 24.12 & 2902 \\
\hline Crude Protein $(\%)$ & 24.15 & 24.11 & 2905 & 1.06 \\
Metabolizable Energy (kcal/kg) & 2905 & 2904 & 1.07 & 0.53 \\
Calcium (\%) & 1.05 & 1.06 & 0.53 & 1.51 \\
Available Phosphorus (\%) & 0.52 & 0.53 & 1.42 & 0.57 \\
Lysine (\%) & 1.38 & 1.40 & 0.56 & 0.82 \\
Methionine (\%) & 0.52 & 0.54 & 0.85 & \\
Cystine (\%) & 0.91 & 0.88 & & \\
\hline
\end{tabular}

\footnotetext{
${ }^{1}$ Analysed value.
}

${ }^{2}$ Premix (provided per kg): $8.800 \mathrm{IU}$ vitamin A, $2.200 \mathrm{IU}$ vitamin D3, $11 \mathrm{mg}$ vitamin E, $44 \mathrm{mg}$ nicotinic acid, $8.8 \mathrm{mg}$ Cal-D-Pan, $4.4 \mathrm{mg}$ riboflavin, $2.5 \mathrm{mg}$ tiamin, $6.6 \mathrm{mg}$ vitamin B12, $1 \mathrm{mg}$ folic acid, $0.11 \mathrm{mg}$ D-biotin, $220 \mathrm{mg}$ choline, $80 \mathrm{mg}$ manganese, $60 \mathrm{mg}$ iron, $5 \mathrm{mg}$ copper, $60 \mathrm{mg}$ zinc, 0.20 $\mathrm{mg}$ cobalt, $1 \mathrm{mg}$ iodine, $0.15 \mathrm{mg}$ selenium

\section{Results}

The differences among the groups fed with different levels of dietary mealworm meal in terms of final body weight and body weight gain were statistically significant $(\mathrm{P}<0.05)$. The highest body weight and soybean meal and soybean oil constituted the 3 experimental treatment groups (Table 1).

In the first week of the study, all quails were fed with control diet. During the next four weeks the quails were fed with 4 diets consisting of different levels of mealworm. The experimental diets were isonitrogenous and isoenergetic and were formulated. Diets met or exceeded requirements and were adjusted according to NRC (1994) Japanese quail nutrition specifications. Feed and water were provided ad libitum.

Body weight and feed intake of quails was determined at weekly during the experiment. Feed conversion ratio (FCR) was calculated as feed intake / body weight gain (FI/BWG). On the last day (35 days) of the experiment, 4 (two male and two female) quails from each replicate were randomly selected and slaughtered. These quails were weighed and cleaned, and then carcass weights were determined.

The data were analyzed by using the ANOVA in Minitab (2000). If the treatments were found to be significantly different, then Duncan's multiple range tests was used to determine the differences among treatments (MStat C, 1995). body weight gain was in the group fed with mealworm meal added to diets at the level of $2 \%$ (Table 2). Final body weight of quails fed with mealworm meal containing 4 and $6 \%$ diets was lower $(\mathrm{P}<0.05)$ than the quails fed with diet containing $2 \%$ mealworm meal Feed intake were not differ $(\mathrm{P}>0.05)$ among the groups. Feed conversion ratio of quails fed diet con- 
taining $4 \%$ and $6 \%$ mealworm meal diets were higher than the quails fed diet control $(0 \%)$ and $2 \%$ of the Table 2

The Effect of Dietary Different Levels of Mealworm on Performance of Quails

\begin{tabular}{lccccc}
\hline $\begin{array}{l}\text { Dietary } \\
\text { mealworm } \\
\text { levels }(\%)\end{array}$ & $\begin{array}{c}\text { Initial Body } \\
\text { Weight }(\mathrm{g})\end{array}$ & $\begin{array}{c}\text { Final Body } \\
\text { Weight }(\mathrm{g})\end{array}$ & $\begin{array}{c}\text { Body Weight } \\
\text { Gain }(\mathrm{g})\end{array}$ & $\begin{array}{c}\text { Feed Intake } \\
(\mathrm{g})\end{array}$ & $\begin{array}{c}\text { Feed Conversion Ratio } \\
(\text { Feed, g/Gain,g) }\end{array}$ \\
\hline 0 & $17.7 \pm 0.20$ & $171.3 \pm 3.78^{\mathrm{ab}}$ & $153.6 \pm 3.72^{\mathrm{ab}}$ & $480.4 \pm 12.5$ & $3.13 \pm 0.04^{\mathrm{b}}$ \\
2 & $17.1 \pm 0.12$ & $173.0 \pm 2.55^{\mathrm{a}}$ & $155.9 \pm 2.48^{\mathrm{a}}$ & $488.6 \pm 6.27$ & $3.14 \pm 0.03^{\mathrm{b}}$ \\
4 & $17.2 \pm 0.12$ & $163.8 \pm 2.28^{\mathrm{bc}}$ & $146.6 \pm 2.27^{\mathrm{bc}}$ & $488.9 \pm 4.13$ & $3.34 \pm 0.06^{\mathrm{a}}$ \\
6 & $17.9 \pm 0.07$ & $161.6 \pm 2.46^{\mathrm{c}}$ & $143.8 \pm 2.45^{\mathrm{c}}$ & $498.3 \pm 3.60$ & $3.47 \pm 0.07^{\mathrm{a}}$ \\
\hline
\end{tabular}

$\overline{a, b, c}$ : Means with different minuscule in the same rows are significantly different at $\mathrm{P}<0.05$.

At the end of the experiment, there was no significant difference between the treatment groups in terms of carcass weights and carcass yield of quails fed with

diets containing different levels of mealworm meal (Table 3 and 4)

Table 3

The Effect of Dietary Different Levels of Mealworm on Carcass Weight of Quails

\begin{tabular}{lccc}
\hline \multirow{2}{*}{\begin{tabular}{l} 
Dietary mealworm levels \\
\cline { 2 - 4 }
\end{tabular}} & \multicolumn{3}{c}{ Carcass Weight (g/quail) } \\
\hline 0 & $124.9 \pm 2.90$ & $133.7 \pm 4.88$ & $129.3 \pm 3.67$ \\
2 & $126.1 \pm 1.32$ & $136.1 \pm 3.06$ & $131.1 \pm 1.32$ \\
4 & $122.9 \pm 3.62$ & $135.1 \pm 5.29$ & $129.0 \pm 1.36$ \\
6 & $120.3 \pm 2.18$ & $125.5 \pm 7.12$ & $122.9 \pm 3.89$ \\
\hline
\end{tabular}

Table 4

The Effect of Dietary Different Levels of Mealworm on Carcass Yield of Quails

\begin{tabular}{lccc}
\hline \multirow{2}{*}{\begin{tabular}{l} 
Dietary mealworm levels \\
\cline { 2 - 4 }
\end{tabular}} & \multicolumn{3}{c}{ Carcass Yield (\%) } \\
\cline { 2 - 4 } & $78.4 \pm 0.66$ & $77.2 \pm 0.36$ & Mean \\
\hline 0 & $75.8 \pm 1.10$ & $74.8 \pm 0.86$ & $76.0 \pm 0.40$ \\
4 & $77.8 \pm 0.42$ & $75.6 \pm 1.52$ & $76.7 \pm 0.73$ \\
6 & $77.1 \pm 0.70$ & $74.7 \pm 1.00$ & $76.2 \pm 0.97$ \\
\hline
\end{tabular}

\section{Discussion}

The present study evaluated the effects of dietary mealworm meal inclusion on growth performance and carcass traits of quails. The body weight, body weight gain and feed conversion ratio of the quails in the present study impaired when fed with diets containing more than $2 \%$ mealworm meal, but did not cause any change in feed intake. The previous study results regarding the mealworm meal utilization in poultry are limited and sometimes controversial. Ramos-Elorduy et al. (2002) reported that the addition of full fat mealworm at different levels between $5 \%$ and $10 \%$ in the diet of broilers fed with soybean meal-based diets did not cause any difference in growth performance. Similarly, Biasato et al. (2016) observed that the addition of $7.5 \%$ mealworm to the diet in free-range chickens fed with corn-soybean-based diets did not significantly affect performance. Bovera et al. (2015) reported that there was no difference in the body weight and body weight gain of the broilers between the group fed with mealworm meal containing rations and the control group. Biasato et al. (2018) suggested that the addition of 5, 10 and $15 \%$ mealworm to diet in male broiler may improve body weight and feed intake, but may adversely affect feed efficiency, so researchers suggested that low levels of mealworm addition to the diet may be more appropriate. The researchers also reported that there was no significant difference in carcass characteristics between the treatment group and the control group. Ballitoc and Sun (2013) reported that containing $0,0.5,1,2$ and $10 \%$ fed with mealworms of broilers may positively affect growth performance and carcass yield, and that $2 \%$ mealworm use in the broiler diets would be appropriate. Işık and Kırkpınar (2016) reported that body weight gain was higher in broilers fed with $6 \%$ mealworm diet than other groups (containing 0 and $2 \%$ of mealworm), but it was similar to containing $4 \%$ mealworm group. During the experiment, no significant difference was found between the groups in terms of feed conversion ratio of broilers. Researchers have suggested that mealworm can be used as a source of protein in broilers up to $6 \%$ without adversely affecting performance.

In conclusion, the use of mealworm meal in quail chicks diets up to $2 \%$ may be appropriate and above this level growth performance may be adversely affected. 


\section{Acknowledgements}

This study is summarized from Hilal SABIRLI's Master's thesis and it's funded by Selçuk University Scientific Research Projects Coordination (Project number 17201118)

\section{References}

Ballitoc DA, Sun S (2013). Ground yellow mealworms (Tenebrio molitor L.) feed supplementation improves growth performance and carcass yield characteristics in broilers. Open Sci. Reposit.Agric. http://dx.doi.org/10.7392/opena-ccess.23050425. e23050425.

Biasato I, Gasco L, De Marco M, Renna M, Rotolo L, Dabbou S, Capucchio MS, Biasibetti E, Tarantola M, Sterpone L, Cavallarin L, Gai F, Pozzo L, Bergagna S, Dezzutto D, Zoccarato I, Schiavone A (2016). Effects of dietary Tenebrio molitor meal inclusion in free-range chickens, Journal of Animal Physiology and Animal Nutrition, 100:1104-1112. DOI: $10.1111 /$ jpn.12487

Biasato I, Gasco L, De Marco M, Renna M, Rotolo L, Dabbou S, Capucchio MS, Biasibetti E, Tarantola M, Sterpone L, Cavallarin L, Gai F, Pozzo L, Bergagna S, Dezzutto D, Zoccarato I, Schiavone A (2018). Yellow mealworm larvae (Tenebrio molitor) inclusion in diets for male broiler chickens: effects on growth performance, gut morphology, and histological findings, Poultry Science 97:540-548

Bovera F, Piccolo G, Gasco L, Marono S, Loponte R, Vassalotti G, Mastellone V, Lombardi P, Attia YA, Nizza A (2015). Yellow mealworm larvae (Tenebrio molitor, L.) as a possible alternative to soybean meal in broiler diets, British Poultry Science, 56:569-575

Bovera F, Loponte R, Marono S, Piccolo G, Parisi G, Iaconisi V, Gasco L, Nizza A (2016). Use of Tenebrio molitor larvae meal as protein source in broiler diet: effect on growth performances, nutrient digestibility and carcass and meat traits. J. Anim. Sci. 94: 639-647.

FAO (Food and Agriculture Organization of the United Nations) (2013). Edible insects - future prospects for food and feed security. FAO Forestry Paper 171, IX.

Hossain SM, Blair R (2007). Chitin utilisation by broilers and its effect on body composition and blood metabolites. Brit. Poultry Sci., 48: 33-38.

Işık Ö, Kırkpınar F (2016). Etlik Piliçlerin Beslenmesinde Alternatif Protein Kaynağ 1 Olarak Un Kurdu (Tenebrio molitor L.)'nun Kullanımı. Hayvansal Üretim, 57(1): 15-21.

Makkar HPS, Tran G, Heuzé V, Ankers P (2014). State of the art on use of insects as animal feed. Anim. Feed Sci. Technol. 197, 1-33.

Minitab I (2000). MINITAB statistical software, Minitab Release, 13.

Mstat C (1980). Mstat Users's Guiide: Statistics (Version, Michigan State University, Michigan, USA.

NRC (1994). National Research Council, Nutrient Requirements of Poultry, 9th revised ed. National Academy Press, Washington, DC, USA.

Ramos-Elorduy J, Gonzàlez EA, Hernàndez AR, Pino JM (2002). Use of Tenebrio molitor (coleoptera: tenebrionidae) to recycle organic wastes and as feed for broiler chickens. J. Echon. Entomol. 95: 214220.

Sánchez-Muros MJ, Barroso FG, Manzano-Agugliaro F (2014). Insect meal as renewable source of food for animal feeding: a review. J. Clean. Prod. 65: 16-27.

Van Huis A (2013). Potential of insects as food and feed in assuring food security. Annu. Rev. Entomol. 58: 563-583.

Veldkamp T, van Duinkerken G, van Huis A, Iakemond CMM, Ottevanger E, Bosch G, Van Boekel MAJS (2012). Insects as a sustainable feed ingredient in pig and poultry diets -a feasibility study. Wageningen UR Livest. Res. Rep. 638. 